\title{
THE COURTS, SOCIAL SCIENCE, AND SCHOOL DESEGREGATION
}

\author{
Hilton Head Island, South Carolina \\ August 20, 1974
}

\section{Conference Attendees}

Carlos M. Alcala, Interim Director of Educational Litigation, Mexican-American Legal Defense and Educational Fund; co-author, Project Report: De Jure Segregation of Chicanos in Texas Schools, 7 Harv. Civ. Rights-Civ. Lib. L. Rev. 307 (1972); J.D. Harvard Law School.

Marguerite R. Barnett, Assistant Professor of Politics \& Public Affairs, Princeton University; co-editor, Political \& Economic Strategies for Black People in the Coming Decades; Ph.D. in Political Science, University of Chicago.

Derrick A. Bell, Professor of Law, Harvard University; author, RaCe, RaCism AND AMERICAN LAw (1973); formerly Director of Western Center on Law and Poverty; special assistant to the Secretary of the Department of Health, Education, and Welfare; attorney, the NAACP Legal Defense and Education Fund, Inc.; attorney, the United States Department of Justice. LL.B. University of Pittsburgh School of Law.

Norman J. Chachkin, Staff Attorney, NAACP Legal Defense and Educational Fund, Inc.; co-author, Metropolitan School Desegregation: Evolving Law, 10 INTEGRATED ED. 13 (1972); formerly in private practice in Arkansas; LL.B. New York University Law School.

Elizabeth G. Cohen, Professor, School of Education and Department of Sociology, Stanford University; Director of the Environment for the Teaching Program at Stanford School of Education; author, A New Approach to A Pplied RESEARCH: RACE AND Education (1970) and of numerous articles on interracial interaction and on the effects of teacher behavior and classroom characteristics on children; Ph.D. in Sociology, Harvard University.

James P. Comer, Associate Professor of Psychiatry and Associate Dean for Student Affairs, Yale University School of Medicine; Chairman, American Psychiatric Association Committee of Black Psychiatrists; author, BEYOND BLACK AND White (1972); author of other articles and books on child development, racism, mental health, and inner city schools; formerly staff member of National Institute of Mental Health; M.D. Howard University; M.A. in Public Health, University of Michigan.

Robert Crain, The Rand Corporation; Director of Emergency School Assistance Program Study, Southern Schools: An Evaluation of the Effects of the Emergency School Assistance Program and of School Desegregation; co-author, Political Strategies in Northern School Desegregation (1973); Discrimination, Personality, and Social Achievement (1972); formerly with Center for Metropolitan Studies, John Hopkins University. 
Ronald R. Edmonds, Director, Center for Urban Studies, Harvard University Graduate School of Education; author, with others, of $A$ Black Response to Christopher Jencks' Inequality and Certain Other Issues, 43 HaRv. ED. REv. 76 (1973); author of other articles on school desegregation; formerly Assistant Superintendent of the Michigan Department of Public Instruction; Human Relations Director of the Ann Arbor Public Schools; Certificate of Advanced Study, Career Program, Harvard Graduate School of Education.

Edgar G. Epps, Marshall Field IV Professor of Urban Education, University of Chicago; co-author, Black Consciousness, Identity and Achievement: A Study of Black College Students (forthcoming); author, Family and Achievement: A Study of the Relation of Family Background to Achievement Orientation and Performance Among Urban Negro High School Students (1969); editor of Black Students in White Schools (1972), Race Relations: Current Perspectives (1973), and of Cultural Pluralism 1974; past Associate Editor of the American Sociological Review; formerly Director of the Division of Behavioral Science Research, Professor of Sociology, and Chairman of the Division of Social Sciences at Tuskegee Institute; Professor, Department of Psychology and the Survey Research Center, University of Michigan; Professor of Sociology, Florida A \& M University; Ph.D. in Sociology, Washington State University.

Reynolds Farley, Associate Professor and Chairman of the Department of Sociology and Associate Director, Population Studies Center, University of Michigan; author of numerous articles on demographic studies bearing on racial issues, two of his most recent appearing in American Sociological Review and the American Journal of Sociology; formerly Assistant Professor of Sociology, Duke University; Ph.D. in Sociology, University of Chicago.

Owen M. Fiss, Professor of Law, Yale University; author, School Desegregation: The Uncertain Path of the Law, 4 Philosophy of Pub. Affairs 3 (1974), The Charlotte-Mecklenburg Case-Its Significance for Northern Desegregation, 38 U. C. HI. L. Rev. 697 (1971); Racial Imbalance in the Public Schools: The Constitutional Concepts, 78 Harv. L. Rev. 564 (1965); formerly Professor of Law, University of Chicago; Special Assistant to the Assistant Attorney General, Civil Rights Division, United States Department of Justice; law clerk to Associate Justice William J. Brennan, Jr., United States Supreme Court; law clerk to Thurgood Marshall, then United States Circuit Judge, U.S. Court of Appeals for the Second Circuit; LL.B. Harvard Law School.

Gordon Foster, Professor of Education, Graduate School of Education and Director of the Florida School Desegregation Consulting Center, University of Miami; author of articles on desegregation in The Urban Review and Harvard Educational Review; conducted desegregation plan studies in 17 states and 20 Florida school districts, master plan studies for 20 school districts in Pennsylvania; member of Desegregation Panel requested by the Federal District Court to prepare a comprehensive plan for metropolitan Detroit; formerly held faculty appointments at Miami University and Ohio State University; Director of Southwestern Ohio Educational Research Council and Central Office Research 
Associate for the Cincinnati Schools; taught secondary schools; Ph.D. in Education Administration, Ohio State University.

F. Chris Garcia, Associate Professor of Political Science, University of New Mexico; author, Political Socialization of Chicano Children: A Comparative Study With Anglos in California Schools (1973); la Causa Politica: A Chicano Politics Reader (1974); Orientations of Mexican American and Anglo Children Toward the U.S. Political Community, 53 Social SCr. Q. 814 (1973); editor, Chicano Politics: Readings (1973); and author of other articles on political influences, political participation, and the political socialization of Mexican-American children; previous teaching appointments at California State University at Fullerton, Indiana University, and University of California at Davis; Ph.D. in Political Science, University of California at Davis.

Willis D. Hawley, Associate Professor, Department of Policy Sciences and Political Science, and Associate Director, Institute of Policy Sciences and Public Affairs, Duke University; author, NonPartisan Elections and The Case for Party Politics (1973); Blacks and Metropolitan Governance: The Stakes of Reform (1972); editor, IMPRoving THE Quality of URBan MaNagement (1974), The Search for Community Power (1968); previously taught at Yale University; former assistant city manager; research associate at the Institute of Governmental Studies of University of California at Berkeley; assistant to the Vice President of the University of California; Ph.D. in Political Science, University of California at Berkeley.

Nathaniel R. Jones, General Counsel, National Association for the Advancement of Colored People; formerly practicing attorney in Ohio; Deputy General Counsel of the President's Commission on Civil Disorders; Assistant United States attorney for the Northern District of Ohio; co-chairman of the National Civilian-Military Task Force on Military Justice; LL.B. Youngstown University.

Brian Landsberg, Chief, Education Section, Civil Rights Division, Justice Department.

Betsy Levin, Associate Professor of Law, Duke University; editor, FUTURE Directions for School Finance Reform (1974); author, Recent Developments in the Law of Equal Educational Opportunity, 4 J. LAw \& ED. 411 (1975); Alternatives to the Present System of Financing Schools: Their Problems and Prospects, 61 Geo. L.J. 879 (1973); co-author, The Financing of Schools in Illinois (1973), The High Cost of Education in the Cities: An Analysis of the Purchasing Power of the Educational Dollar (1973), The Political Limits to Education Finance Reform (1973), Schools and Taxes in North Carolina (1973), Paying for Public Schools: Issues of School Finance in California (1972), Public School Finance: Present Disparities and Fiscal Alternatives (1972); former teaching positions at Georgetown University Law Center and Yale Law School; Director of Education Studies, The Urban Institute; Special Assistant and White House Fellow to Hon. Arthur J. Goldberg; law clerk to Simon E. Sobeloff, U.S. Circuit Judge for the Court of Appeals for the Fourth Circuit; LL.B. Yale Law School. 
Henry M. Levin, Associate Professor, School of Education and Department of Economics, Stanford University; author, Vouchers and Social Equity, 5 Change no. 8, at 29 (1973), The Costs to the Nation of Inadequate Education, a report for Senate Select Committee on Equal Educational Opportunity, monograph on educational vouchers (in preparation); editor (and co-author of chapter) of Community Control of SCHOOLS (1970); joint author, Schools And INEQUALITY (1971); author of numerous other articles on educational finance; vice president of the American Educational Research Association; former Research Associate in Social Economics, The Brookings Institution, Associate Research Scientist in the Graduate School of Public Administration at New York University; Ph.D. in Economics, Rutgers University.

Constantine C. Menges, Deputy Assistant Secretary for Education, Department of Health, Education, and Welfare; author of articles on the evaluation of federal education programs; other positions in HEW; staff member, The Rand Corporation; former assistant professor of political science at University of Wisconsin; staff of the Institute of War and Peace Studies, Columbia University, and the Hudson Institute.

Jane R. Mercer, Associate Professor of Sociology, University of California at Riverside; author, Labelling the Mentally Retarded: Clinical and Social Systems Perspectives on Mental Retardation (1973); joint author, RaciallEthnic Segregation and Desegregation in American Public Education, 73 Nat'L Social Stud. Yrbk. pt. 2, at 274 (1974); author, Policy Statement on Assessment Procedures and the Rights of Children, 44 HARv. ED. Rev. 125 (1974), IQ: The Lethal Label, 38 ED. DigeST 17 (1973), Sociocultural Factors in Labeling Mental Retardates, 48 PEabody J. ED. 188 (1970); author of numerous other articles on factors contributing to adjustment and achievement in racially desegregated schools and evaluations of desegregated education; Associate Editor of Sociology of Education and Consulting Editor for the American Journal of Mental Deficiency; Ph.D. in Sociology, University of Southern California.

Gary Orfield, Research Associate, The Brookings Institution, 1972-73 Scholarin-Residence, U.S. Commission on Civil Rights; author, The Reconstruction of Southern Education: The Schools and the 1964 Civil Rights Act (1969), Congressional Power: Congress and Social Change (1975), Federal Policy, Local Power, and Metropolitan Segregation, 89 Pol. ScI. Q. 777 (1974-75), School Integration and its Academic Critics, 5 Civil Rights Digest 2 (Summer 1973); formerly held teaching positions at the University of Virginia and Princeton University; Ph.D. in Political Science, University of Chicago.

Thomas F. Pettigrew, Professor of Social Psychology and Sociology, Harvard University; author or co-author of seven books on race relations, including Racially Separate or Together (1971) and A Profile of the Negro AMERICAN (1964); other books in press or preparation, including Social PSychology and American RaCe Relations; author of many articles on race relations and education; former president of the Society for the Psychological Study of Social Problems, and Associate Editor of the American Sociological Review; member of the 1967 White House Task Force on Education; Ph.D. Social Psychology, Harvard University. 
Frank T. Read, Dean, University of Tulsa Law School; co-author, LET THEM BE Judged: The Judicial Integration of the Deep South (forthcoming), formei Professor of Law and Associate Dean, Duke University; J.D. Duke Law School.

Sanford J. Rosen, Legal Director, Mexican-American Legal Defense and Educational Fund; author, The Law and Racial Discrimination in Employment, 53 Calif. L. Rev. 729 (1965), Equalizing Access to Legal Education: Special Programs for Law Students Not Admissible by Ordinary Criteria, 1970 U. Toledo L. REv. 321 ; former Assistant Legal Director, ACLU; Professor of Law, University of Maryland Law School; law clerk to Simon E. Sobeloff, U.S. Circuit Judge, U.S. Court of A ppeals for the Fourth Circuit; LL.B. Yale Law School.

Joshua L. Smith, Program Officer, The Ford Foundation; author, FreE Schools: Pandora's Box?; co-editor, Removing Barriers to Humaneness in THE High Schools (1971); former Executive Secretary of the Citizens Advisory Committee on Racial Equality in Education (in Pittsburgh), high school administrator, and public school teacher; Ed.D. Harvard Graduate School of Education.

William L. Taylor, Director, Center for National Policy Review and Adjunct Professor of Law, Catholic University School of Law; author, Hanging Together: Equality in an Urban Nation (1971), Federal Civil Rights Laws: Can They Be Made to Work?, 39 Geo. WASH. L. Rev. 971 (1971), Legal Battle for Metropolitanism, 81 School Rev. 331 (1975), The Supreme Court and Urban Reality: A Tactical Analysis of Milliken v. Bradley, 21 Wayne L. Rev. 751 (1975), The Justice Department and Race Relations, 12 InTEGRATED Ed. no. 2, at 5 (1974), Law as a Catalyst for Change: The Mississippi Experience, 50 N.C.L. REv. 1038 (1972), and many other articles on civil rights, school desegregation, and busing; former Director of the U.S. Commission on Civil Rights; Secretary of the Sub-Cabinet Group on Civil Rights; Staff Attorney for the NAACP Legal Defense and Educational Fund, Inc; LL.B. Yale Law School.

Meyer Weinberg, Professor of History, City Colleges of Chicago, and Lecturer, School of Education, Northwestern University; Editor, Integrated Education; currently preparing third edition of DESEgREgation RESEARCH: AN ApPRAISAL, and second edition of a bibliography on EDUCATION OF THE MINORITY CHILD; numerous other articles and books on school desegregation; M.A. University of Chicago.

Frederick $M$. Wirt, Director, Policy Sciences Graduate Program at University of Maryland, Baltimore County; co-author, The Political Web of American Schools (1972), The Politics of Southern Equality: Law and Social Change in a Mississippi County (1971); co-editor, School Desegregation in the North: The Challenge and Experience (1968), The Search for Community Power (2d ed. 1974); joint author, On the City's Rim: Politics And Policy in Suburbia (1972); editor of a series of books on public education; former Director of the Institute for School Desegregation Problems at Berkeley; Research Political Scientist, Institute of Governmental Studies and Lecturer, School of Education, University of California at Berkeley; former member of faculty, Denison University; Ph.D. in Political Science, Ohio State University. 
Hon. John M. Wisdom, United States Circuit Judge, United States Court of Appeals for the Fifth Circuit since his appointment by President Eisenhower in 1957; formerly partner in Wisdom, Stone, Pigman \& Benjamin; LL.B. Tulane University.

Mark G. Yudof, Professor of Law, University of Texas; co-author, Educational Policy and the Law (1974), Serrano in the Political Arena, 2 Yale Rev. Law \& Social Action 143 (1971), Rodriguez v. San Antonio Independent School District: Gathering the Ayes of Texas-The Politics of School Finance Reform, 38 LAw \& Contemp. Prob. 383 (1974); author, Property Tax in Texas under State and Federal Law, 51 Texas L. Rev. 885 (1973), Equal Educational Opportunity and the Courts, 51 Texas L. Rev. 411 (1973), Indian Education: Federal Funds for Public Schools, 7 INequality in ED. 20 (1972); former Research Associate and Senior Staff Attorney, Center for Law and Education, Harvard University; Lecturer, Harvard School of Education; law clerk to Robert A. Ainsworth, Jr., U.S. Circuit Judge, Court of Appeals for the Fifth Circuit; LL.B. University of Pennsylvania Law School. 